\title{
Evaluation of High-Sensitivity C-Reactive Protein and Serum Lipid Profile in Southeastern Nigerian Women with Pre-Eclampsia
}

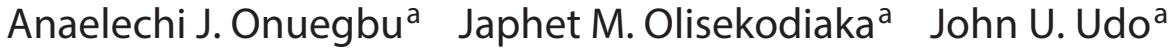 \\ Osita Umeononihu ${ }^{b}$ Ubuoh K. Amah ${ }^{a}$ John E. Okwara ${ }^{a}$ Chidiadi Atuegbu ${ }^{a}$ \\ Departments of a Chemical Pathology and ${ }^{\mathrm{b}}$ Obstetrics and Gynaecology, College of Health Sciences, Nnamdi \\ Azikiwe University, Nnewi, Nigeria
}

\section{Key Words}

Pre-eclampsia · C-reactive protein - Triglycerides .

Total cholesterol $\cdot$ High-density lipoprotein cholesterol

\section{Abstract}

Objective: To evaluate the serum C-reactive protein (CRP) and lipid profile in women with pre-eclampsia. Materials and Methods: Thirty-five women with and 35 women without pre-eclampsia, who were in the 3rd trimester of pregnancy, were enrolled in this study. Weight in kilogrammes and height in metres were measured to calculate the mean body mass index (BMI) for each group. The diastolic and systolic blood pressures were measured. Lipid profile tests and serum CRP assay were done for all patients. Total cholesterol, triglycerides (TG) and high-density lipoprotein cholesterol (HDL-C) were determined using enzymatic methods, while low-density lipoprotein cholesterol (LDL-C) was calculated using Friedewald's formula. Results: The mean values of the BMI were $29.47 \pm 6.90$ versus $26.14 \pm 2.92$, of the diastolic blood pressure $109.14 \pm 15.41$ versus $72.29 \pm 9.42 \mathrm{~mm} \mathrm{Hg}$ and of the systolic blood pressure $170.57 \pm 19.55$ versus $120.86 \pm 17.72 \mathrm{~mm} \mathrm{Hg}$ for women with and without pre-ec- lampsia, respectively, and the differences were statistically significant ( $p=0.012, p=0.001$ and $p=0.001$, respectively). The biochemical analysis also indicated that the women with pre-eclampsia had a significantly higher mean serum CRP ( $8.57 \pm 2.68$ vs. $6.46 \pm 2.46 \mathrm{mg} / \mathrm{l}, \mathrm{p}=0.001), \mathrm{TG}(2.84 \pm 0.45$ vs. $1.87 \pm 0.38 \mathrm{mmol} / \mathrm{l}, \mathrm{p}=0.001)$ and total cholesterol (5.59 \pm 0.92 vs. $4.63 \pm 0.78 \mathrm{mmol} / \mathrm{l}, \mathrm{p}=0.001)$ level but a lower mean HDL-C (1.10 \pm 0.12 vs. $1.26 \pm 0.15 \mathrm{mmol} / \mathrm{l}, \mathrm{p}=0.001)$ level than the controls. There was no statistical difference in the mean LDL-C values between the 2 groups ( $1.58 \pm 0.8$ vs. $1.45 \pm 0.78 \mathrm{mmol} / \mathrm{l}, \mathrm{p}>0.05)$. Conclusion: Significant changes in CRP as well as TG, total cholesterol and HDL-C were associated with pre-eclampsia in these Southeastern Nigerian women.

(c) 2015 S. Karger AG, Basel

\section{Introduction}

Pre-eclampsia is a complication of pregnancy characterized by hypertension and proteinuria [1]. It is a major cause of perinatal and maternal mortality that affects $3-10 \%$ of pregnancies worldwide [2], and its prevalence

\begin{tabular}{|c|c|}
\hline KARGER 125 & $\begin{array}{l}\text { (C) } 2015 \text { S. Karger AG, Basel } \\
1011-7571 / 15 / 0243-0276 \$ 39.50 / 0\end{array}$ \\
\hline $\begin{array}{l}\text { E-Mail karger@karger.con } \\
\text { www.karger.com/mpp }\end{array}$ & $\begin{array}{l}\text { This is an Open Access article licensed under the terms of the } \\
\text { Creative Commons Attribution-NonCommercial } 3.0 \text { Un- } \\
\text { ported license (CC BY-NC) (www.karger.com/OA-license), } \\
\text { applicable to the online version of the article only. Distribu- } \\
\text { tion permitted for non-commercial purposes only. }\end{array}$ \\
\hline
\end{tabular}

Dr. Anaelechi J. Onuegbu

Department of Chemical Pathology, College of Health Sciences

Nnamdi Azikiwe University, Nnewi Campus

PMB 5001, Nnewi, Anambra State (Nigeria)

E-Mail ja.onuegbu@unizik.edu.ng 
in Nigeria ranges from about 2 to $16.7 \%$ [3-5]. The aetiology of this disease has not been well elucidated. There are multiple factors implicated in its pathogenesis. Among the many proposed causes are immunological derangement (a maternal immune reaction to paternal antigen in the placenta), genetic factors, increased insulin resistance and subsequent oxidative stress with associated endothelial dysfunction [6]. A growing number of studies suggest that systemic inflammation demonstrated by increased $\mathrm{C}$-reactive protein (CRP) and significant changes in lipid and lipoprotein levels could be associated with pre-eclampsia [7-9]. However, Savvidou et al. [10] suggested that the onset of clinical signs of pre-eclampsia may not be preceded by a maternal inflammatory response as assessed by the measurement of CRP.

There are indications that obesity may be a vehicle through which inflammation could cause pre-eclampsia [9, 11]. An elevated body mass index (BMI) has been reported to be associated with increased risk of pre-eclampsia [12]. A study by Ramsay et al. [13] indicated that an increased BMI in early pregnancy is associated with increased systolic blood pressure, triglyceride (TG) concentration, insulin levels and lower high-density lipoprotein (HDL).

Although previous studies $[8,9]$ have shown an association between CRP, lipids and pre-eclampsia, this has not been confirmed across different populations since these studies included mostly North American and European women. The objective of this study was therefore to determine the lipid profile and CRP among Southeastern Nigerian women with pre-eclampsia and to compare them with healthy pregnant controls to ascertain whether these parameters were associated with pre-eclampsia in this population.

\section{Materials and Methods}

The study population included pregnant women attending the Department of Obstetrics and Gynaecology and the Antenatal Clinic of Nnamdi Azikiwe University Teaching Hospital (NAUTH) in Nnewi, Southeastern Nigeria. The protocol for the study was approved by the Ethics Committee of the hospital, and informed written consent was obtained from each participant before the investigations were started. Thirty-five women with and 35 without pre-eclampsia, who had a similar range for age, gestational age and parity, were enrolled in the study. Pre-eclampsia was defined as a blood pressure of $\geq 140 / 90 \mathrm{~mm} \mathrm{Hg}$, measured twice at least $6 \mathrm{~h}$ apart, and proteinuria of $\geq 300 \mathrm{mg} / \mathrm{dm}^{3}$ or $\geq+1$ using a urine dipstick [14].

Assessment of Cardiovascular and Inflammatory Markers

The women's weight and height were measured in kilogrammes and metres, respectively, using a medical grade weighing scale and stadiometer (model Stat Fax 2100, Awareness Technology Inc., Palm City, Fla., USA). The BMI of each woman was then calculated. A well-structured questionnaire was used for the collection of information on the demographics and socio-economic status of the participants. After an overnight fast, each participant's blood was drawn from the cubital vein into a plain test tube using a sterile needle and syringe. The samples were allowed to clot, and the serum was separated by centrifugation for $10 \mathrm{~min}$ at 4,000 rpm and stored at $-20^{\circ} \mathrm{C}$ until the time of analysis. ELISA kits (Abnova, Taipei City, Taiwan) were used for the analysis of the serum CRP, while the serum total cholesterol, HDL cholesterol (HDL-C) and TG were estimated by spectrophotometric methods (kits obtained from Randox Laboratories, Crumlin, UK). Serum low-density lipoprotein cholesterol (LDL-C) was calculated using Friedewald's formula [15].

\section{Statistical Analysis}

The SPSS statistics version 20 (IBM, Armonk, N.Y., USA) was used for all statistical analysis. Student's t test was used to compare the data of the 2 groups of participants, and statistical significance was accepted at $\mathrm{p}<0.05$.

\section{Results}

The demographics, BMI and blood pressure measurements are given in table 1 . The women with pre-eclampsia had a significantly higher BMI (29.47 \pm 6.90 vs. $26.14 \pm 2.92, \mathrm{p}=0.012)$, systolic $(170.57 \pm 19.55$ vs. $120.86 \pm 17.72 \mathrm{~mm} \mathrm{Hg}, \mathrm{p}=0.001)$ and diastolic (109.14 \pm 15.41 vs. $72.29 \pm 9.42 \mathrm{~mm} \mathrm{Hg}, \mathrm{p}=0.001$ ) blood pressure compared to the controls. The values of the CRP and lipid profile are given in table 2. The CRP values were significantly higher in the group with pre-eclampsia compared to the corresponding control $(8.57 \pm 2.68$ vs. $6.46 \pm 2.46 \mathrm{mg} / \mathrm{l}, \mathrm{p}=0.001)$. The difference in LDL-C levels between the 2 groups was not statistically significant ( $1.58 \pm 0.8$ vs. $1.45 \pm 0.78 \mathrm{mmol} / \mathrm{l}, \mathrm{p}>0.05)$, while the mean serum HDL-C was significantly lower in the group with pre-eclampsia compared to the control group $(1.10 \pm 0.12$ vs. $1.26 \pm 0.15 \mathrm{mmol} / \mathrm{l}, \mathrm{p}<0.005)$. The mean total cholesterol $(5.59 \pm 0.92$ vs. $4.63 \pm 0.78$ $\mathrm{mmol} / \mathrm{l})$ and serum TG $(2.84 \pm 0.45$ vs. $1.87 \pm 0.38$ $\mathrm{mmol} / \mathrm{l})$ levels were all significantly increased in the group with pre-eclampsia when compared to the control group ( $\mathrm{p}<0.005$ and $\mathrm{p}<0.005$, respectively). Furthermore, there were no significant differences in the mean concentrations of serum CRP, TG, LDL and HDL when women with a lower BMI $(\leq 24.9)$ were compared with those with a high BMI $(\geq 25)$. However, the mean serum total cholesterol was significantly higher in women with a higher BMI (table 3). 
Table 1. Age, gestational age, BMI and blood pressure measurements in women with and without pre-eclampsia

\begin{tabular}{lccc}
\hline Parameters & $\begin{array}{l}\text { With } \\
\text { pre-eclampsia } \\
(\mathrm{n}=35)\end{array}$ & $\begin{array}{l}\text { Without } \\
\text { pre-eclampsia } \\
(\mathrm{n}=35)\end{array}$ & $\begin{array}{l}\mathrm{p} \\
\text { value }\end{array}$ \\
\hline Age, years & $30.91 \pm 5.92$ & $28.89 \pm 4.28$ & 0.105 \\
Gestational age, weeks & $33.83 \pm 4.96$ & $33.89 \pm 4.13$ & 0.958 \\
BMI & $29.47 \pm 6.90$ & $26.14 \pm 2.92$ & 0.012 \\
SBP, mm Hg & $170.57 \pm 19.55$ & $120.86 \pm 17.72$ & 0.001 \\
DBP, mm Hg & $109.14 \pm 15.41$ & $72.29 \pm 9.42$ & 0.001 \\
\hline
\end{tabular}

Values represent means \pm standard deviation. SBP $=$ Systolic blood pressure; DBP = diastolic blood pressure.
Table 2. CRP and lipid profile of the women with and without preeclampsia

\begin{tabular}{llll}
\hline Parameters & $\begin{array}{l}\text { With } \\
\text { pre-eclampsia } \\
(\mathrm{n}=35)\end{array}$ & $\begin{array}{l}\text { Without } \\
\text { pre-eclampsia } \\
(\mathrm{n}=35)\end{array}$ & $\begin{array}{l}\mathrm{p} \\
\text { value }\end{array}$ \\
\hline $\mathrm{CRP}, \mathrm{mg} / \mathrm{l}$ & $8.57 \pm 2.68$ & $6.46 \pm 2.45$ & 0.001 \\
$\mathrm{HDL}-\mathrm{C}, \mathrm{mmol} / \mathrm{l}$ & $1.10 \pm 0.12$ & $1.26 \pm 0.15$ & 0.001 \\
LDL-C, mmol/l & $1.58 \pm 0.81$ & $1.45 \pm 0.78$ & 0.492 \\
TC, $\mathrm{mmol} / \mathrm{l}$ & $5.59 \pm 0.92$ & $4.63 \pm 0.78$ & 0.001 \\
TG, $\mathrm{mmol} / \mathrm{l}$ & $2.84 \pm 0.45$ & $1.87 \pm 0.38$ & 0.001
\end{tabular}

Values represent means \pm standard deviation. TC $=$ Total cholesterol.
Table 3. Blood pressure, CRP and lipid profile of the women based on their BMI

\begin{tabular}{lcccc}
\hline Parameters & $\begin{array}{l}\text { BMI } \leq 24.9 \\
(\mathrm{n}=19)\end{array}$ & $\begin{array}{l}\text { BMI } \geq 25.0 \\
(\mathrm{n}=51)\end{array}$ & t value & p value \\
\hline BMI & $23.16 \pm 0.94$ & $29.53 \pm 5.52$ & 24.84 & 0.001 \\
Age, years & $27.84 \pm 5.81$ & $30.67 \pm 4.83$ & 4.23 & 0.04 \\
SBP & $144.21 \pm 29.49$ & $146.27 \pm 31.99$ & 0.06 & 0.81 \\
DBP & $87.37 \pm 20.23$ & $91.96 \pm 23.33$ & 0.57 & 0.45 \\
CRP & $7.02 \pm 2.97$ & $7.70 \pm 2.67$ & 0.84 & 0.36 \\
TC & $4.78 \pm 1.12$ & $5.28 \pm 0.88$ & 3.82 & 0.05 \\
TG & $2.22 \pm 0.62$ & $2.39 \pm 0.65$ & 1.11 & 0.29 \\
HDL & $1.14 \pm 0.14$ & $1.21 \pm 0.16$ & 2.68 & 0.11 \\
LDL & $1.35 \pm 0.91$ & $1.59 \pm 0.74$ & 1.33 & 0.25 \\
TC/HDL & $4.29 \pm 1.39$ & $4.46 \pm 1.05$ & 0.31 & 0.58 \\
\hline
\end{tabular}

Values represent means \pm standard deviation. $\mathrm{SBP}=$ Systolic blood pressure; DBP $=$ diastolic blood pressure; TC $=$ total cholesterol.

\section{Discussion}

In this study, the BMI in women with pre-eclampsia was significantly higher than in women without pre-eclampsia; also, the mean systolic and diastolic blood pressures were significantly higher in women with pre-eclampsia. These findings confirmed those of Mirzaie et al. [16] and Ghorashi and Sheikhvatan [17]. However, the BMI did not change significantly between the 2 groups in these studies [16, 17].

The significantly higher serum CRP, TG and total cholesterol levels and the lower HDL level in women with pre-eclampsia of our study were similar to those of previous studies $[7,8]$. These findings (ours and those of the above previous studies) would indicate that these high serum CRP, TG and total cholesterol and lower HDL lev- els might be associated with pre-eclampsia. The CRP, primarily produced by the hepatocytes, is a sensitive marker of non-specific tissue damage and inflammation and has been suggested to play a role in eliciting the inflammatory response characteristic of pre-eclampsia [18]. Zimmerman et al. [19] and Mantovani and Dejana [20] demonstrated a relationship between inflammation and endothelial dysfunction, and it was further revealed that markers of endothelial activation or inflammation have an active role in pre-eclampsia [21]. The significantly high level of CRP in these cases might not be related to the BMI, even though CRP has been strongly associated with BMI, and the link between obesity and pre-eclampsia appears to be well established [22]. This is because insignificant changes were observed in the mean serum CRP concentration of both the low and the high BMI lev- 
el, which would suggest that the BMI was not a confounding factor. The significantly high levels of TG and total cholesterol with significantly low HDL-C could reflect a compromised vascular function. These explanations agree with a study by Catarino et al. [23], who reported that pre-eclampsia is associated with an enhanced hyperlipidaemia which seemed to have a negative impact on fetal lipid profile as reflected by an atherogenic LDL-C/ HDL-C ratio and higher TG levels. Oestrogen (the female sex hormone) is also believed to induce hepatic biosynthesis of endogenous TG, which is carried by very lowdensity lipoprotein (VLDL) [24]. This process may be modulated by hyperinsulinaemia, also found in pregnancy [25]. HDL is an anti-inflammatory agent and is involved in reverse cholesterol transport which it achieves by carrying excess, potentially harmful cholesterol to the liver for excretion [26]. Gohil et al. [27] stated that, in their own opinion, pre-eclampsia is a complex pathophysiological state where the regulatory system of inflam- mation and endothelial function is most often stimulated beyond the physiological limits of normal pregnancy.

A major limitation of this study, however, is the small sample size. Further studies with larger sample sizes are still required to shed more light on the pathophysiology of pre-eclampsia with a view to predicting, preventing and assisting in the management of such conditions.

\section{Conclusion}

In this study, there were significantly higher mean levels of serum CRP, total cholesterol and TG and a significantly lower mean concentration of serum HDL-C in women with pre-eclampsia compared to those without. The net effect of the significant changes in CRP, TG, HDL-C and total cholesterol as obtained in this study could possibly be associated with pre-eclampsia in these Nigerian women.

\section{References}

-1 Ramma W, Ahmed A: Is inflammation the cause of pre-eclampsia? Biochem Soc Trans 2011;39:1619-1627.

$>2$ Baumwell S, Karumanchi SA: Pre-eclampsia: clinical manifestations and molecular mechanisms. Nephron Clin Pract 2007;106 72-81.

3 Omole-Ohonsi A, Ashimi A: Pre-eclampsia a study of risk factors. Niger Med Pract 2008; 53:99-102.

4 Olopade F, Lawoyin T: Maternal mortality in a Nigerian maternity hospital. Afr J Biomed Res 2008;11:267-273.

$\checkmark 5$ Mbachu I, Udigwe G, Okafor C, et al: The pattern and obstetric outcome of hypertensive disorders of pregnancy in Nnewi, Nigeria. Niger J Med 2013;22:117-122.

6 Solomon C, Seely E: Hypertension in pregnancy. A manifestation of the insulin resistance syndrome. Hypertension 2001;37:232239.

7 Kashanian M, Aghbali F, Mahahi N: Evaluation of the diagnostic value of the first trimester maternal serum high-sensitivity C-reactive protein level for prediction of preeclampsia. J Obstet Gynaecol Res 2013;39: 1549-1554.

$>8$ Dey M, Arora D, Narayan N, et al: Serum cholesterol and ceruloplasmin levels in second trimester can predict development of preeclampsia. N Am J Med Sci 2013;5:41-46.

-9 Van Rijn BB, Veerbeek JH, Scholtens LC, et al: C-reactive protein and fibrinogen levels as determinants of recurrent pre-eclampsia: a prospective cohort study. J Hypertens 2014; 32:408-414.
10 Savvidou MD, Lees CC, Parra M, et al: Levels of C-reactive protein in pregnant women who subsequently develop pre-eclampsia. BJOG 2002;109:297-301.

11 Wolf M, Kettyle E, Sandler L, et al: Obesity and pre-eclampsia: the potential role of inflammation. Obstet Gynecol 2001;98:757-762.

12 Kabiru W, Raynor B: Obstetric outcomes associated with increase in BMI category during pregnancy. Am J Obstet Gynecol 2004;191: 928-932.

13 Ramsay JE, Ferrel WR, Crawford L, et al: Maternal obesity is associated with dysregulation of metabolic, vascular and inflammatory pathways. J Clin Endocrinol Metab 2002;87: 4231-4237.

14 American College of Obstetricians and Gynecologists; Task Force on Hypertension in Pregnancy: Hypertension in pregnancy: report of the American College of Obstetricians and Gynecologists' Task Force on Hypertension in Pregnancy. Obstet Gynecol 2013;122: 1122-1131.

15 Friedwald TW, Fredrickson DS, Levy RJ: LDL cholesterol estimation. Clin Chem 1972;18: 499-501.

16 Mirzaie F, Fatemeh R, Amir H: Association of maternal serum C-reactive protein levels with severity of pre-eclampsia. Acta Med Iran 2009; 47:293-296.

17 Ghorashi V, Sheikhvatan M: The relationship between serum concentration of free testosterone and pre-eclampsia. Endokrynol Pol 2008;59:390-392.

18 Ustun Y, Engin-Ustun Y, Kamaci M: Association of fibrinogen and C-reactive protein with severity of pre-eclampsia. Eur J Obstet Gynecol Reprod Biol 2005;121:154-158.

19 Zimmerman GA, Prescott, SM, McIntyre TM: Endothelial cell interaction with granulocytes, tethering and signaling molecules. Immunol Today 1992;13:93-100.

20 Mantovani A, Dejana E: Cytokines as communication signals between leukocytes and endothelial cells. Immunol Today 1989;10: 370-375.

21 Teran E, Escudero C, Moya W, et al: Elevated $\mathrm{C}$-reactive protein and pro-inflammatory cytokines in Andean women with pre-eclampsia. Int J Gynaecol Obstet 2001;75:243-249.

22 Bodmar LM, Ness RB, Harger GF, et al: Inflammation and triglyceride partially mediate the effect of prepregnancy body mass index on the risk of pre-eclampsia. Am J Epidemiol 2005;162:1198-1206.

23 Catarino C, Rebelo I, Belo L, et al: Fetal lipoprotein changes in pre-eclampsia. Acta Obstet Gynaecol Scand 2008;87:628-634.

24 Glueck CJ, Fallet RW, Scheel D: Effects of oestrogenic compounds on triglyceride kinetics. Metabolism 1975;24:537-545.

25 Adegoke O, Iyare E, Gbenebitse S: Fasting plasma glucose and cholesterol levels in pregnant Nigerian women. Niger Postgrad Med J 2003; 10:32-36.

26 Rothblat GH, Phillips MC: High-density lipoprotein heterogeneity and function in reverse cholesterol transport. Curr Opin Lipidol 2010;21:229-238.

27 Gohil JT, Patel PK, Gupta P: Estimation of lipid profile in subjects of pre-eclampsia. J Obstet Gynaecol India 2011;61:399-403. 